\title{
RECOGNITION OF TRADITIONAL HANDICRAFTS AS CULTURAL VALUES TO TOURISM: A MODEL SUGGESTION FOR AFYONKARAHISAR
}

\author{
Özcan Zorlu ${ }^{59}$ \\ Ali Avan 60
}

\begin{abstract}
From 2000s and on, product diversification initiatives in tourism have gained momentum based on ever-changing context of tourism experiences. Such experiences that shed light into respect to nature and traditional culture instead of mass tourism activities have become focal point both for tourism supply and demand. Within this development trend, culture tourism is one of the most increasing-developing tourism activity among others. Culture tourism underpins to serve natural and cultural attractions, cultural activities and popular artworks as a tourism value. It also offers an opportunity to gain economic value for traditional handicrafts for developing destinations. Thus, certain handicrafts rarely used in daily life could be marketed as a cultural value and they generate economic income for the region. Setting off with this fact, it is aimed in this research to carry out a model in order to make the traditional handicrafts of Afyonkarahisar into touristic assets. Afyonkarahisar has a wide range of characteristic handicrafts such as making felt, harness craft for horses, making horse carriage, blacksmithing and copper craft, hand-printed head-scarf making and etc. After all, most of these crafts are manufactured low in numbers due to the absence of craftsmen. On the other hand, all these handicrafts are valuable to serve as a part of culture tourism. Therefore, within this scope, firstly, an inventory including handicrafts and craftsmen in the region was conducted. Then, a SWOT analyses was performed to traditional handicrafts in Afyonkarahisar. Finally, a model was built in line with strategic planning and some suggestions/explanations were made concerning the model.
\end{abstract}

Keywords: Culture Tourism, Traditional Handicrafts, Marketing, Strategic Planning.

\section{INTRODUCTION}

In today's tourism market, tangible and intangible cultural values of a nation provide an important competitive advantage for any destination in terms of alternative tourism activities. These values can both market along with mass tourism and separately as culture or cultural heritage tourism. In tourism settings, heritage and culture may be used for a variety of purposes, including entertainment, preservation, information, education, profit and propaganda. For the local residents the themes may be ordinary and familiar, but to visitors these same themes may be unique, exotic and extraordinary, and characterized by differentness from the visitors' own normal environment (Prideaux, Timothy, 2008:2). Historical attractions, monuments, or landmarks,

${ }^{59}$ Asst. Professor, Department of Tour Guidance, Faculty of Tourism, Afyon Kocatepe University, 03200, Afyonkarahisar. Turkey.

${ }^{60}$ Asst. Professor, Department of Tourism Management, Faculty of Tourism, Afyon Kocatepe University, 03200, Afyonkarahisar, Turkey. 
museums, art galleries, or theaters, festivals, concerts, or performances, culturally significant neighborhoods or communities are the main attractions for cultural heritage tourism. Tourists who are interested in cultural heritage generally want to learn something about the beliefs and practices that shaped the shared identity of a people (McNulty and Koff, 2014: 7). Cultural heritage tourism is representative of many tourist to directly experience and consume diverse past and present cultural landscapes, performances, foods, handicrafts, and participatory activities (Chhabra, Healy and Sills, 2003: 703). Hence, beneficiary countries of cultural tourism encourage the preservation of cultural heritage as an asset for all the community (du Cros, 2001: 166) including traditional handicrafts (THCs).

As an expression of a culture in any city, region or country handicrafts are an essential for tourism. On the other hand tourism in a region leads to the emergence of souvenir industry, which thrives mostly on local handicrafts (Chutia and Sarma, 2016: 108). Handicrafts that are the subject of tourism are local manifestation of the social construction of identity and tradition. There is a huge variety of handicraft products because of the influence of the regions where the crafts come from, the natural resources used, the indigenous origin, traditions and customs, and the artisan's creativity and skill (Giron, Hernandez and Castenada, 2007: 16). In countries attracting a large number of international visitors, the tourism sector offers many opportunities for the local people to sell handicrafts, as tourists spend significant amounts of money on souvenirs and other craft products. Furthermore, strengthening the handicraft sector ensures that tourists choose to buy more locally produced handicraft items rather than imported products, and handicraft production can help diversify the tourism product including home-stays, cultural experiences. Handicraft production provides the communities with an opportunity to preserve their natural and cultural heritage and exposes it to international visitors. Handicraft production is a labour intensive industry that can support a number of part-time and fulltime employees, both skilled and unskilled. Additionally, craftsmen can learn how to diversify their product base and they can add value to their business along with learning new skills to enhance the sustainability of their business (ITC Technical Paper, 2012).

With its great potential for cultural heritage tourism and the emphasis given in the literature, this study focuses on THCs manufacturing in Afyonkarahisar. The study consists of three parts except for the conclusion. In the first part, THCs and its linkage with cultural heritage tourism is discussed in line with existing literature. The following part represents a brief information about THCs producing in Afyonkarahisar. The last part of the study contains findings obtained from the results of semi-structured interviews and secondary data analysis. This part also presents a SWOT analysis for THCs in Afyonkarahisar, and a development model on the basis of strategic management. 


\section{LITERATURE REVIEW}

\section{Traditional Handicrafts and Cultural Tourism}

THCs are a part of the culture of a nation and represent a key component of socioeconomic life. THCs closely linked with folk rituals, festivities and culture. Based on this fact, THCs have been preserved over the centuries without loss of intrinsic quality (Dhamija, 1975, 460). THCs have been a vehicle for conveying the feelings and artistic pleasures of the societies with a great diversity for centuries. A variety of factors such as value judgments in the period of production, political tendencies in society, economic situation, religion, interpersonal relations, attitudes and behaviors of people, technical tools and equipment, skills, aesthetic point of view and designing of products affect the formation of handicrafts (Kahveci, 1998, 387). In 1969, International Trade Centre defined handicrafts as the products, which are made with or without the use of tools, simple instruments or implements operated directly by craftsmen, mainly by hand or by foot. Identifying features of these products are; a) traditional or artistic features deriving from geographical region or country of production, b) production by craftsmen, working generally on a cottage industry basis (Gaur, 2011). UNESCO consider THCs as a part of Intangible Cultural Heritage (ICH) by defining ICH. They define IHC as "intangible cultural heritage means the practices, representations, expressions, knowledge, skills - as well as the instruments, objects, artefacts and cultural spaces associated therewith - that communities, groups and, in some cases, individuals recognize as part of their cultural heritage. ICH is manifested inter alia in oral traditions and expressions, performing arts, social practices, rituals and festive events, knowledge and practices concerning nature and the universe, traditional craftsmanship (UNESCO, 2003: 2).

Today, THCs are also considered as a home-based industry by creating several jobs at a minimal cost. Production of THCs mainly based on existing skills of artisans and availability of raw materials. With its cost-efficient inputs and specific production process THCs can generate regular additional income especially for rural societies that provide financial independence (Richard, 2007: 5). Furthermore, THCs provide an important advantage in reducing poverty in developing countries. This advantage arises from the use of cheap raw materials and simple technology, which are easily obtainable in production. Many handicraft products can be obtained with an investment that requires very little capital. In addition; when compared to industrial production, craftsmen face fewer barriers to investment. However, THCs production can be sustained in people's homes, family settings, shared times and lifestyles (Akhal et al., 2008: 5).

THCs are cultural forms of expression that are transformed into tangible products of technical and aesthetic accumulation conveyed from the past. The production of 
handicrafts transmitted from one generation to another also provides the transfer of cultural heritage (Ertürk and Yetim, 2015: 519). Thus, THCs are an important part of cultural heritage. Hence, most countries encourage the preservation of heritage as an asset for all the community. Heritage can be used to evoke a sense of continuity of culture, enrichment of people's lives, as a link with the past and to allow society to make sense of the present (du Cros, 2001: 166). However, the changing social structure and lifestyle have also changed the role of THCs in everyday life. Today, handicraft production in developing countries now depends in large part on the demand generated by the tourism industry and by the business activities of intermediaries (Richard, 2007: $6)$.

Changes in tourism demand (from mass tourism to sustainable individual touristic activities) also push THCs to forefront in terms of culture tourism. Horner and Swarbrooke (2007: 35-36) state, "the desire to experience other current cultures and view artefacts (including handicrafts) of previous cultures has been a motivator in the tourism market since Greek and Roman times. Today it is extremely popular and is often viewed as a good form of tourism.... Today, cultural tourism is the core of the tourism product in many countries and is the main reason why tourists visit these countries". Together with the past civilizations, lifestyle, tradition, customs, festivals, music and entertainment types, handicrafts, food types and habits are among the most important products of cultural tourism (Bayazit, Ceylan and Saylan, 2012: 901). In other words, THCs are an important component of cultural -heritage- tourism. Hence, one of the most important values within the socio-cultural heritage that is unique to tourists' experiences is THCs. THCs are an integral part of tourism. Tourists do not refrain from purchasing souvenir items that symbolize the THCs of their destination. THCs reflect local traditions and people living in the destination. In addition, they are the means of representing places, experiences and shared memory that they visit for tourists (Akhal et al., 2008: 5).

\section{An overview about Traditional Handicrafts of Afyonkarahisar}

Traditional Turkish handicrafts are the values that reflect Turkish cultural riches through the social feelings of the Turkish people. Turkish handicrafts have created a rich synthesis by combining their own values with the cultural heritage of various civilizations from the thousands of year old Anatolia. Carpets and rugs, fabric weaving, writing, gold and silver works, tile making, pottery, embroidery, sculpture, leatherwork, musical instruments, marble work, copper work, basket making, saddlery, felt making, wood and wood works are basics of Turkish THCs (Can, 2013: 260).

Although Afyonkarahisar is generally popular with thermal tourism, cultural tourism and religious tourism, the destination has important THCs in terms of cultural heritage 
tourism as well. Afyonkarahisar was popular with THCs in 1800s and diversity of THCs in Afyonkarahisar is still remarkable (Küçükkurt and Arsoy, 2001: 138). According to Afyonkarahisar Provincial Culture and Tourism Directorate (APCTD), there are eleven different handicrafts, which could be considered as THCs. These traditional handicrafts are felt making, harness craft for horses, making horse carriage, blacksmithing and copper craft, hand-printed head-scarf making, kilim and carpet weaving (traditional rug), wicker knitting/matting, marble sculpture, knitting, lace and needlepoint making (Afyonkarahisar 1 Kültür ve Turizm Müdürlüğü, 2015). However, there were small-scaled bazaars in the past, according to the kinds of THCs. Today, some of these THCs have gradually decreased; even some of them are almost extinct (Küçükkurt and Arsoy, 2001: 138). A short brief about three main THCs of Afyonkarahisar is given below.

a) Kilim and Carpet Weaving (traditional rug); Although carpet weaving was an important source of livelihood in the late 1980s, it lost its importance in time. Today, commercial carpet weaving is being carried out in Örenköy, which is the county of Emirdağ. On the other hand, kilim weaving is still popular in various settlements of Afyonkarahisar (Arsoy, 2004: 393). Prayer rug, pillowcase, saddlebag, carpetbag, mushaf and other souvenirs made from carpet are the most popular types of carpet and kilim weaving. In particular, the reputation of the rugs produced in the Bayat has extended abroad. (Afyonkarahisar 1 Kültür ve Turizm Müdürlüğ̈̈). Afyon Kilims have a very rich pattern and composition, and kilims of every village are unique in terms of composition. Tree of life is the most popular motif at kilim weaving in Afyonkarahisar (Küçükkurt and Arsoy, 2001: 142-143).

b) Felt making: Felt making, which has an important place in Afyon handicrafts, was eventually manufactured and sold in more than 150 shops at the end of $19^{\text {th }}$ century. The felts were used in many places throughout history. However, the usage area of the felt has decreased day by day with the development of the industry and technology. Hence, today there are only 3 or 4 felt factories in Afyonkarahisar. Felt crafters manufacture a variety of furnishings and products such as felt rug, prayer rug, shepherd's felt cloak, whirling dervish fez, swaddle, boot and booties, fez and tarboosh, door curtain, sedar mat, runner, door mat, saddlebag and camel muzzle (Küçükkurt and Arsoy, 2001: 146-147; Arsoy, 2004: 386-387).

c) Harness craft for horses and making horse carriage: Harness is a strip kit (belt), which is needed in order to run the horse carriage to horse; and harness making is a very old profession in Afyonkarahisar. To make harness, crafters 
firstly buy buffalo skins from the butchers and alum them to make straps to use at harnesses. In addition, they glamourize these belts with hand-made fringes and tassels. Horse carriage making is a very old profession that became popular with harness profession. Horse carriages generally use as freightage vehicle and phaeton. As a freightage vehicle, horse carriages are meticulously made from wood and glamourized with different motifs. Generally, landscape or creative figures are used for glamourizing. Although harness craft and horse carriage profession were very popular in the past, these professions have lost their importance parallel to the decline of horse carts (Afyonkarahisar 1 Kültür ve Turizm Müdürlüğ̈̈).

\section{METHODOLOGY}

This study particularly focuses on recognition of traditional handicrafts. In the study, it is primarily aimed to make an inventory about traditional handicrafts manufactured in Afyonkarahisar. Then, it is aimed to perform SWOT analysis by considering culture tourism and to form a model to recognition and marketing of THCs as cultural values. Within this context, secondary data analysis and semi-structured interviews were conducted from 15 July to 30 August 2017. Secondary data analysis were mainly consisted of traditional handicrafts literature review based on cultural heritage tourism and determination of basic statistics about handicrafts was carried out via scanning written and/or online documents presented by different institutions. Semi-structured interviews involve face-to-face meetings with different craftsmen, qualified instructors and local authorities. With these interviews, it was primarily aimed to form a frame for current position of aforementioned handicrafts that consists the number of craftsmen for each handicraft, the number of shops, sales level, incentives and etc. In addition to results of the interviews, we also obtained some information from Provincial Culture and Tourism Directorate of Afyonkarahisar to draw a development strategy.

In the analysis process, interview forms were studied by researchers and two consultants in an effort to determine key themes of the research. This process involved open and blind coding which provides key words as well. Then the research data were reviewed and reported in accordance with predetermined themes and SWOT analysis was performed. Finally, all components were brought together to set a model for recognition and development of traditional handicrafts in Afyonkarahisar including some practical and managerial suggestions.

\section{FINDINGS}

The danger of extinction of existing values is one of the most important threats to the societies' culture. These values include any value that can be assessed in terms of ICH. 
The values of traditional handicrafts, which constitute the focus point of this study, have fallen into oblivion in Turkey as well as in many other countries. Furthermore, the situation is not different in Afyonkarahisar province, which also constitutes the research area. Our interviews and the data obtained from provincial directorate of culture and tourism indicate that there are only few artisans making traditional handicrafts such as felt making, copper work, harness craft and making horse carriage. However, felt craft is relatively better since there are four or five artisans still making felt. Even, there is a family that has been operating on the ground for five generations. Provincial directorate of culture and tourism statistics indicate that there are nineteen people dealing with felt making. However, only five of them manufacture felt crafts. There are five coppersmiths and only two of them actively are engaged in this job. Similarly, there are five harness artisans but only two of them are still manufacturing harness. Ten craftsmen are still producing marble-works (Afyonkarahisar 1 Kültür ve Turizm Müdürlügüi). Although lace and needlepoint manufacturing is very popular among housewives in Afyonkarahisar, we could not get any certain statistics about the number of them.

The maintenance of the performing crafts require consistent knowledge sharing and continuous communication since these all crafts require certain qualities specific to their own. Craftsmen can only differentiate by having relevant craft at his/her fingertips. Additionally, that kind of knowledge sharing and communication is needed in terms of raw material procurement and handicraft supplying to the tourists. However, in the study, it is observed that artisans have some communication problems with other artisans who are making the same handicraft. Participants' opinions about the subject are as follows: "We take into account each detail at every stage from the supply of the raw material until the product meets the tourist. Therefore, we have our brand value and they are looking for us first to buy relevant handicraft.", "Handcraft in other words manual dexterity is very important. As an artisan, my entire fund is available in my mind and my fingers, and, I got this fund with sixty years of experience. This is why sometimes, other artisans are ignoring me."

The sustainability of the master-apprentice relationship is of great importance in the survival of the ICH values. However, for this, there should be a noteworthy demand to relevant handicrafts. In the study, it has been understood that it is very difficult to survive these professions in today's conditions due to the future anxiety of the professions practiced as traditional hand techniques and due to limited financial means. Participants stated that: "There is no demand in learning this crafts as a profession. There are only those who want to learn handcraft for a very short period. However, what can you teach them in a week or two weeks?"," There is not anyone who is learning these crafts, instead there is mechanization everywhere"," Even my children do not want to learn my profession. When we get retired or leave, this craft will soon 
end, may it will be forgotten", "There is only a person working with me, we have been together for 40 years, then there is no one."

Values produced in the context of traditional handicrafts have their unique structure. Therefore, their raw materials could be very different and could not be obtained easily. For this reason, artisans have to calculate the supply of raw materials and costs as well. In addition, although crafts are typically named as traditional, they also need to adapt to the needs of the times and meet people's expectations and needs. Starting from this point of view, artisans take care to make their craft appropriate for the innovations. This situation leads to increases in costs, and it necessitates the establishment of a small logistical network for the supply of raw materials. Based on this fact, participants were asked whether there were any problems in the raw material procurement process. Some of their expressions for felt making follow as: "There is a raw material problem. We have a lot of raw material but we have difficulty in finding quality material we want." "We use imported materials. Because the native material cannot respond to our needs due to the loss of native race. The material I use is about 12-13 dollars. I can supply the same material for 50 cents from Turkey, but it is poor quality. Domestic material is generally 35-40 micron, but imported material always is 25 micron, in other words it has a standard". Some expressions for copper work are: "In Afyonkarahisar there is no copper mine. Thus, we have to buy copper plate from Manisa and then we melt it.", as for horse carriage production; "The tree we use is brought here from Adapazarl. Because we need hard and resistant wood material. On the other hand, we can use new and old irons. When you melt old iron, it becomes a new raw material. Therefore, we usually exchange used iron materials to produce new ones. In addition, our raw materials' cost is very high. Thus, we have some difficulties not only in supplying due to the financial reasons but also in selling due to the its high price".

One of the most important tasks in maintaining traditional crafts and transforming them into touristic values belongs to the local governments and the stakeholders in the tourism industry, which we can characterize as the upper mind. These actors' contribution to the artisans in terms of raw materials, manufacturing and display area, financing etc. will contribute to the demand of the related craft branches, which are very difficult to sustain and to be transformed into touristic value. The participants' opinions regarding the support of local governments and tourism stakeholders in the survey are as follows: "We cannot get adequate support. Additionally, I do not expect any support as long as it is a benefit" ,"We manufactured a throne cover for the Queen of England which is made from felt. Without anyone's support, they found and got contact with us. Then we manufactured their order and sent it to them.", "We cannot get any support in terms of financial or raw material support. These are not merits, but 
even a central display space where we can meet crafts with people will be very useful to us."

Transformation of traditional handicrafts into touristic values is crucial in passing these handicrafts to the next generations. Today, tourists are more interested in authentic values because of previous experiences they have or they hear. Traditional handicrafts are part of the authentic experience of tourists. Participants' opinions on the evaluation of handicrafts as touristic values: "We have a proverbial saying, 'One may be a help to others and yet neglect one's family and oneself." "Although we have guests from all over the world our own people are unaware of our existence. Research and development activities are needed. Otherwise, these values will gradually disappear. Why we not use them in tourism?"

It is very important to follow certain strategies in presenting traditional handicrafts as tourism value. Thus, all the stakeholders, either directly or indirectly involved in the preservation and transfer of handicrafts to future generations, must act in line with common goals. In the survey, participants expressed the following opinions regarding the presentation of traditional handicrafts as tourism value. "These handicrafts must be sold in the hotels and at major shopping centers. They also should be sold not only to Europe, but to the whole world." "Handicrafts must be made suitable for daily use. In addition, creative ideas must be taken into consideration. Tourists will then show more interest to these crafts." "Different products should be created. For instance, we manufacture presidential seal, prayer rug, paintings with felt or lace. We also send many felt products to presidential palace".

\section{DISCUSSION}

As it is well known and mentioned before, THCs are an important component of ICH tourism activities. On the other hand, these values should be promoted and presented to tourists via efficient management and marketing strategies. In other words, a destination should manage its traditional handicrafts in terms of strategic management to use these values as a tourism product. Thus, firstly a SWOT analysis must be done to determine current position and future actions of THCs. Results of the interviews and data obtained from local authorities indicate that Afyonkarahisar has important resources in terms of THCs. However, the quantity of craftsmen manufacturing gradually are decreasing parallel to increasing fabrication and ever changed needs of people in day life. In addition, there is a lack of awareness about using these values as a tourism source. Within this context, a SWOT analysis matrix towards THCs of Afyonkarahisar is given below. 
Table 2: SWOT Analysis of THCs manufactured in Afyonkarahisar

\begin{tabular}{|c|c|}
\hline Stre & Threats for \\
\hline $\begin{array}{l}\text {-A wide range of handicrafts (more than } \\
\text { 13). } \\
\text {-The presence of experienced craftsmen. } \\
\text {-High-quality und } \\
\text { manufacturing. } \\
\text {-Change-oriented efforts with creative } \\
\text { ideas. } \\
\text {-Positive image throughout Turkey. } \\
\text {-Creative ideas to product } \\
\text { diversification. } \\
\text {-Initiatives towards teaching profession } \\
\text { to young people. }\end{array}$ & $\begin{array}{l}\text {-Declining importance of Handcrafts in } \\
\text { daily life. } \\
\text {-Increasing fabrication and urbanization. } \\
\text {-Danger of being unable to find artisans } \\
\text { in the near future. } \\
\text {-Increasing awareness about using THCs } \\
\text { as a cultural value at other destinations. } \\
\text {-Risks of taking the patent by others } \\
\text { (provinces or countries). } \\
\text {-Stealing the role of the artisans by self- } \\
\text { taught artists. }\end{array}$ \\
\hline $\begin{array}{c}\text { Weaknesses of THCs in } \\
\text { Afyonkarahisar }\end{array}$ & $\begin{array}{c}\text { Opportunities for THCs in } \\
\text { Afyonkarahisar }\end{array}$ \\
\hline $\begin{array}{l}\text {-Gradually decrease at the quantity of } \\
\text { craftsmen. } \\
\text {-Absence of shops due to the high-costs. } \\
\text {-Absence of showrooms to promotion. } \\
\text {-Staff (employee) shortage. } \\
\text {-Inefficient supports and incentives. } \\
\text {-Difficulties at raw material supply. } \\
\text {-Lack of awareness. } \\
\text {-Absence of marketing THCs as a } \\
\text { tourism product. } \\
\text {-Absence of promotion. } \\
\text {-Absence of cultural tourism } \\
\text { development master plan. } \\
\text {-Undeveloped cultural heritage tourism. } \\
\text {-Absence of destination management } \\
\text { mechanism. } \\
\text {-Absence of initiatives at licensing and } \\
\text { patent. }\end{array}$ & $\begin{array}{l}\text {-High potential for cultural heritage } \\
\text { tourism. } \\
\text {-Increasing awareness about using THCs } \\
\text { as a touristic product. } \\
\text {-Product diversification opportunities. } \\
\text {-Ever increasing popularity of } \\
\text { Afyonkarahisar in terms of thermal } \\
\text { destination and the integration possibility } \\
\text { of THCs marketing with thermal/spa } \\
\text { tourism. } \\
\text {-Improvements in transportation (int. } \\
\text { airport, high-speed train investments and } \\
\text { etc.). } \\
\text {-Efforts to teach and to expand THCs } \\
\text { manufacturing. } \\
\text {-Gaining competitive advantage by means } \\
\text { of manufacturing with low-cost raw } \\
\text { materials. }\end{array}$ \\
\hline
\end{tabular}

As seen in Table 1, there are some deficiencies in the use of THCs as touristic values in terms of cultural heritage tourism. High-costs, inadequate promotion and marketing efforts, absence of a master plan towards cultural tourism, unawareness and unconsciousness make up the main problems at manufacturing THCs and using them as a cultural value. However, Afyonkarahisar has high potential for cultural tourism with its numerous cultural values such as martyrs memorials (Kocatepe, Çiğiltepe, e.g), 
historical battlefields, inns and caravanserais, mosques and Islamic-ottoman social complexes (külliye), museums and World Cultural Heritage Sites (Phrygian Valley, Mound of Çavdarl1), festivities (cherry fest, sour-cherry fest, music fest, jazz fest, marble handicrafts fest e.g) and traditional cuisine. In addition to these cultural richness, the utilization rate of cultural values is very low. In other words, Afyonkarahisar could not create any remarkable demand for cultural tourism. Furthermore, there is not any statistics about cultural tourists and cultural tourism income for Afyonkarahisar. Within this context, THCs are not used for cultural tourism as well. Thus, a well-planned strategy must be implemented to develop cultural tourism and to use THCs as an ICH as a part of cultural tourism. Starting from this point of view, a development model is given below (Figure 1) concerning THCs by using as a cultural value.

The THC development model and its main paths shown in Figure 1 set a course for using THCs of Afyonkarahisar as touristic values. The designated model is consisted of four stages starting from planning which is followed by preparation and implementation process. Conservation and providing sustainably stage is the last but may be the most important stage of the model. Because, it is clear from the interviews that there are few artisans and most of them are already old and retired. In other words, if a trainee could not learn handicrafts manufacturing, these precious values will be lost in a near future. Thus, non-governmental organizations (NGOs) and governmental organizations (GOs) must open handicraft courses that will be free of charge and accessible for everyone. On the other hand, a cultural tourism master plan should be declared immediately with the participation of all stakeholders. Marketing and promotion activities should be carried out in accordance with this master plan. Meanwhile public support should be provided so as to open showrooms. In addition, NGOs and GOs should raise public awareness about touristic use of THCs. In other saying, local residents should be aware of THCs economic potential as a touristic product and should keep their traditions. At this point, new THCs could be manufactured with creative ideas towards daily using. 


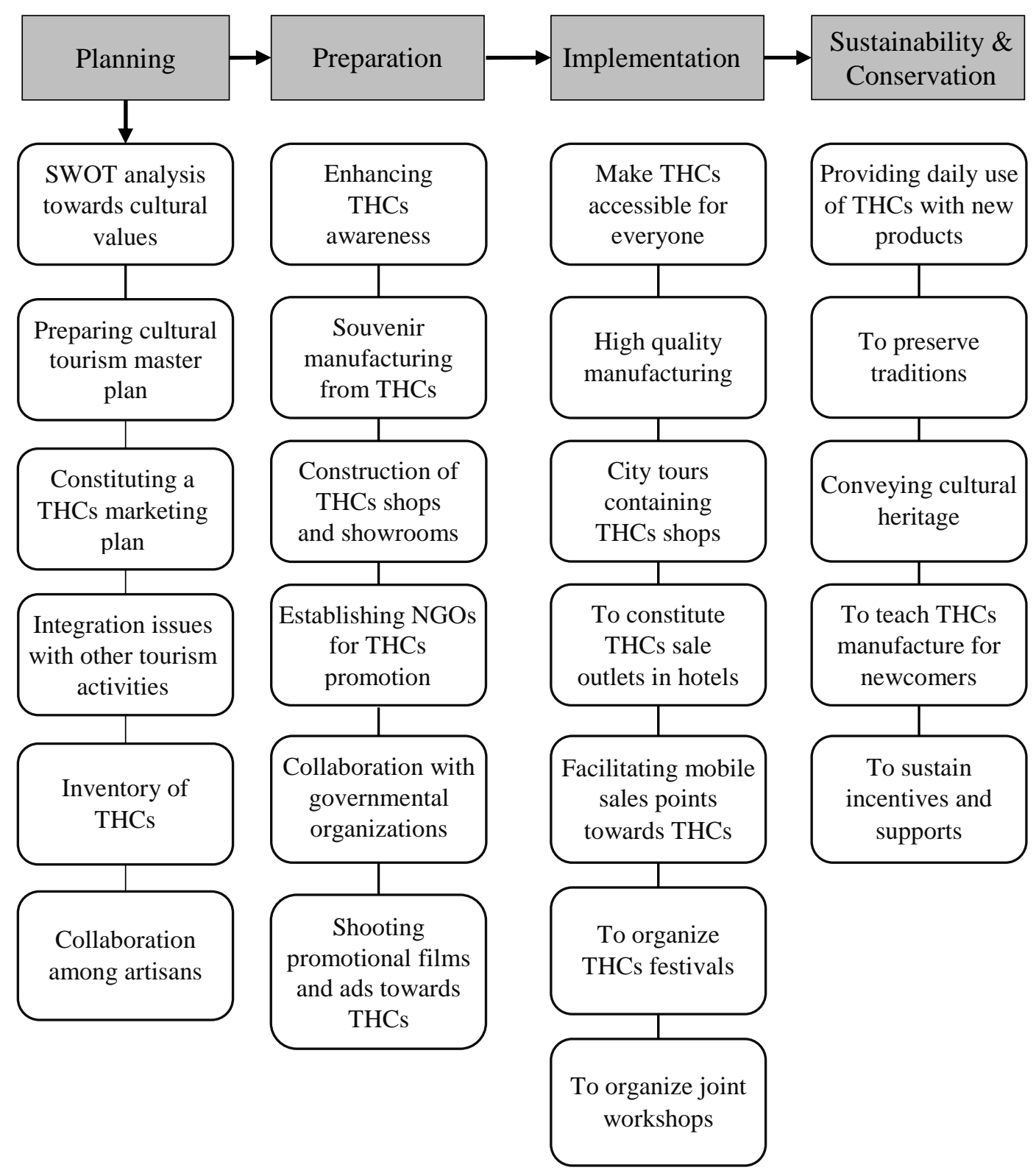

Figure 5: THCs development model for Afyonkarahisar in terms of cultural tourism

In Afyonkarahisar, there are five festivals in the field of agricultural products, marble and music. In addition to these fests, municipality and governorship of Afyonkarahisar should organize traditional handicrafts fest together. Additionally, manufactured THCs should be exhibited in hotels, and a regular city tour must be organized to the THCs factories. Hereby, the popularity and the recognition level of THCs could be increased. Promotional films and ads will also contribute this popularity since they are widely watched and acclaimed. In addition to all these, cultural tourism activities including the 
visit of THCs must be increased via promotional and marketing efforts. THCs should also be promoted with other tourism activities such as thermal tourism, medical tourism, belief tourism, ecotourism e.g.

\section{CONCLUSION}

This study, which is conducted in the field of recognition of THCs as a cultural value, has some important findings in terms of strategic planning and policymaking. First, Afyonkarahisar owns a high potential at cultural heritage tourism with its characteristic THCs. Particularly, felt making, coppersmith, lace and needlepoint works, and marble works could be promoted as a cultural value separately or as integrated with other tourism products. To this, NGOs, GOs and local residents must take joint action and the use of handicrafts should be encouraged. A detailed cultural tourism inventory of Afyonkarahisar should be prepared as a basic resource for further marketing efforts and a master plan. Teaching THCs manufacturing, raising awareness of THCs, organizing fests and promotional activities, conveying them to next generations are the other critical issues within the context of THCs marketing as a touristic value. Eventually, recognition of THCs as cultural values to tourism requires a shared wisdom and efficient marketing and promotion strategies with the participation of all stakeholders.

Although this study contains some important findings, it also includes some limitations due to the several reasons. Lack of extensive literature and research in this field limit the discussion of results. Additionally, this study was conducted only in Afyonkarahisar via semi-structured interviews. Nevertheless, broader studies must be carried out for better understanding of the subject. Tendencies and viewpoints of local people about THCs could be searched with the help of quantitative studies. Comparative studies could also be carried out in terms of identifying competitive edge of Afyonkarahisar at cultural tourism and THCs manufacturing. Results of this study also could be a resource for further studies concerning traditional handicrafts with different aspects.

\section{REFERENCES}

1. Afyonkarahisar 1 Kültür ve Turizm Müdürlüğü (2015). Geleneksel El Sanatları.[Online]Available: http://www.afyonkulturturizm.gov.tr/TR,63456/geleneksel-el-sanatlari.html

2. Akhal, R., Shabaneh, A., \& Tyroler, C. (2008). Handicraft Sector in Aqaba: Diagnostic. Strategy and Action Plan Development, Program, Aqaba Community and Economic Development (ACED) Program-iv, United States Agency for International Development USAID, [Online] Available: 


\section{http://www.aced-jordan.com/files/publication attachments/Handicraft\%}

\section{Sector\% 20in\% 20Aqaba}

3. Arsoy, N. (2004). Afyon El Sanatlart. In Anadolu'nun Kilidi Afyon. (Eds: Uyan, M. and Yüksel, .) pp. 382-402. Afyonkarahisar: Afyon Valiliği Yayınları.

4. Chhabra, D., \& Healy, R., \& Sills, E. (2003). Staged Authenticity and Heritage Tourism. Annals of Tourism Research, 30(3), 702-719.

5. Chutia, L. J., \& Sarma, M. K. (2016). Commercialization of Traditional Crafts of South and South East Asia: A Conceptual Model based on Review of Literature. IIM Kozhikode Society \& Management Review, 5 (2), 107-119.

6. Dhamija, J. (1975). Handicrafts: A Source of Employment for Women in Developing Rural Economies. Int'l Lab. Rev., 112, 459.

7. Du Cros, H. (2001). A New Model to Assist in Planning for Sustainable Cultural Heritage Tourism. International Journal of Tourism Research, 3(2), 165-170.

8. Ertürk, F., \& Yetim, F. (2015). Afyonkarahisar li Antikacılarında Bulunan Hesap şi şlemeli Ürünler Üzerine Bir Araştırma. Journal of International Social Research, 8 (36), 518-534.

9. Girón, J. D. L. P. H., Hernández, M. L. D., \& Castañeda, M. C. (2007). Strategy and Factors for Success: The Mexican Handicraft Sector. Performance Improvement, 46 (8), 16-26.

10. Horner, S., \& Swarbrooke, J. (2007). Consumer Behaviour in Tourism. Second Edition, Butterworth-Heinemann, Oxford, UK.

11. ITC Technical Paper (2012). Inclusive Tourism: Linking the Handicraft Sector to Tourism Markets [Online] Available:

http://www.intracen.org/uploadedFiles/intracenorg/Content/Exporters/Sectoral Information/Service Exports/Tourism/Linking\%20the\%20Handicraft $\% 20$ Secto r\%20reprint\%209\%2010\%202012\%20for\%20web.pdf.

12. Kahveci, M. (1998). 21. Yüzyıla Girerken Geleneksel Türk El Sanatlart. Folkloristik Dursun Yıldırım Armă̆anı. [Online] Available:

http://turkoloji.cu.edu.tr/HALKBILIM/mucella kahveci 21.yuzyila \%20girerken_geleneksel_turk_el_sanatlari.pdf

13. Küçükkurt, Ü., \& Arsoy, N. (2002). Afyonkarahisar El Sanatları. In: Afyonkarahisar Kütü̈̆̈̈ Cilt II, (Eds.: Küçükkurt, ., Uyan, M., Karazeybek, M., Daşdemir, L. ve lgar, Y.). pp: 137-150. Afyon Kocatepe Üniversitesi Yayınları, Yayın No: 35

14. McNulty, R., \& Koff, R. (2014). Cultural Heritage Tourism. Washington, DC.: Livable Communities.

15. Prideaux, B., \& Timothy, D. (2013). Themes in Cultural and Heritage Tourism in Asia and the Pacific. In Cultural and heritage tourism in Asia and the Pacific, (Prideaux, B., Timothy, D., \& Chon, K. Eds.). pp: 1-17. Routledge, Newyork. 
16. Richard, N. (2007). Handicrafts and Employment Generation for the Poorest Youth and Women. Intersectoral Programme on the Cross-Cutting Theme "Poverty Eradication, Especially Extreme Poverty" Policy Paper, (17). Paris: United Nations Educational, Scientific and Cultural Organization.

17. UNESCO (2003) Convention for the Safeguarding of the Intangible Cultural Heritage.[Online]Available:

http://unesdoc.unesco.org/images//0013/001325/132540e.pdf 